\title{
Deregulation of Interest: Implication for National Development
}

\author{
* ERAVWOKE KESTER ERHIEYOVWE (Ph.D) AND ** ESHENAKE JIMOH SAMUEL \\ * College of Education, Mosogar ** College of Education, Warri
}

\begin{abstract}
This paper investigates the deregulation of interest and its implication to national development in Nigeria. Utilizing annual time series data from 1970 to 2018, the study applied augmented dickey fuller unit root test. Overall, our results show that money supply have very strong influence on deregulation in the Nigerian economy. The result equally showed that interest rate, exchange rate, money supply and availability of credit are significant first difference. Thus, the paper submits that deregulation of interest rate has positive impact on exchange rate in Nigeria and recommends among others that efforts should be geared towards maintaining deregulation of interest rate, measure to enhance exchange rate and encourage savings should be maintained with a view to removing all impediments to free flow of businesses in the country.
\end{abstract}

Keywords: Deregulation, Interest rate, economic development, exchange rate

DOI: $10.7176 / \mathrm{JESD} / 10-12-01$

Publication date:June $30^{\text {th }} 2019$

\section{Introduction}

Interest rate is relevant in equilibrating influence on supply and demand in the financial sector in an economy. Colander 2001 and Ojo 1993 have confirmed this by saying that the channeling of savings into financial assets and the willingness of individuals to incur financial liabilities is strongly influenced by interest rates on those financial assets and liabilities. Interest rate has a developmental role of interlocking linkages between the real and financial sectors of most economies. The rate of Interest is a major instrument of monetary policy in Nigeria; interest rate plays a major role in the mobilization of financial resources with the aim of promoting economic development and growth through investment. The rate of interest plays positive relationship between investment and economic development if well established; it therefore becomes imperative that for any economy that wishes to grow should pay proper attention to variation of the rate of interest. Nigeria as a developing economy craving for economic growth and development cannot overlook the importance of interest rate in this direction.

The Nigerian economy had a lot of structural distortions in the early 1980's that almost led to stagnations of key productive sectors in the economy. The economy policies pursued in Nigeria prior to1985 made the economy vulnerable to external shocks. Consequently, budgetary allocation of 1986 sought to deemphasize controls and adopted policy aimed at expanding or increasing the economy resources base. The deregulation policy with its implied structural adjustment is the process by which government removes unnecessary control which tends to inhabit or prevent the effective and efficient program of economic and business activities in developing countries 
Journal of Economics and Sustainable Development ISSN 2222-1700 (Paper) ISSN 2222-2855 (Online) Vol.10, No.12, 2019

like Nigeria. Deregulation can also be said to include elimination or reduction of laws and regulations that hinder free competition in supply of goods and services, thus allowing market forces in driving the economy.

Deregulation of an economy has some important advantages that includes, raising the level of competitiveness, more efficiency, lower prices of goods and services and higher productivity. Deregulation policy was designed to restructure and diversify the productivity of the economy in order to reduce dependency on the oil sector and also to achieve fiscal and balance of payment viability. In addition it lay basis for sustainable non-inflationary or minimal inflationary growth rate.

In the work of Soyibo and Adekanye (1992), Nigerian economy have witnessed financial repression in the early 1980s, interest rates and exchange rates were rigid thus leading to low direct investment from both domestic and foreign investors, funds were inadequate for proper investment in the economy as there was a general lull in the economy, monetary and credit aggregates moved rather sluggishly. Consequently as a result of these anomalies, there was a persistent pressure on the financial and monetary system which in turn necessitated a liberalized financial system. The Nigerian government via the CBN (Central Bank of Nigeria) announced the deregulation of interest rate with effect from 1st August 1987 in its bulletin of July $31^{\text {st }}$ No 21, 1987 as part of the Structural Adjustment Program (SAP) policy package introduced in 1986. The official position of the structural adjustment programme then was that interest rate liberalization would among others enhance the provision of sufficient fund for investment, especially the productive or manufacturing sectors who are considered to be prime agents that drive an economy in promoting growth and development. By implication they are seen as promoters of economic growth. However, in a dramatic policy reversal, the government in January 1994 out-rightly introduced some measures of regulations to interest rate management as it was claimed that there were "wide variations and unnecessarily high interest rates" under the complete deregulation of interest rate. Immediately, deposits were once again set at 12 to 15 percent per annum, while a ceiling of 21 percent per annum was fixed as lending rate. The year 1996 witnessed a full deregulation of interest rates and re emergence of commercial banks being able to negotiate rates with customers, thus, leading to the pursuit of flexible interest rate regime in which bank deposit and lending rates were largely determined by the forces of supply and demand of funds.

\section{LITERATURE REVIEW}

Deregulation of the economy comes in as a result of depression. Depression is said to be a period when there is severe and prolonged down turn in the economy, prices fall, reducing purchasing power. It also resulted into high unemployment, lower productivity, shrinking wages and general economic depression. In essence financial depression according to Oriji (1987), refers to the distribution of domestic financial market through measured such as calling on interest rate and credit expansion, selective allocation of credit and high reserve requirement. It is believed that misguided policies have damaged the economy of Nigeria by reducing saving activities. In essence, the standard recommendation put in place to resuscitate the economy is proper deregulation of the economy which will definitely affect the financial sector. 
In the work of Adekanye (2002) deregulation policy was adopted in 1987 against a crash in the international oil market and the reactant deteriorating economic condition in the country due to stringent policies in the financial sector. Adekanye pointed out that the policy was adopted to achieve fiscal balance and balance of payment availability as well as liberation of the financial system by altering and restructuring the production and consumption pattern of the economy, eliminating price distortions, reducing the heavy dependency on crude oil export and consumer goods importation, enhancing the non-exports base and achieving sustainable growth. The banking sector by its nature of activities is the most heavily regulated sector in most economics. It is based on this criterion that the success of Nigeria's experiment with economic deregulations must inevitably be assessed.

\section{Concept of SAP (Structural Adjustment Programme)}

The structural adjustment progrmme is a free market economy where economic policy reforms are imposed on developing or third world countries by the international monetary fund (IMF) or the World Bank as a condition for giving out loans to such country. The structural adjustment programme was established in the mid 1980s as criteria for gaining stronger influence over economies or countries that is debt trapped in the south. Ensuring continuous inflow of funds, countries seriously in need of fund or devastated by debt obligation have no choice but to adhere to conditions as given by the world bank and international monetary fund. Structural adjustment programme was established to further improve a country's foreign direct investment by eliminating investment and trade regulations to increase foreign exchange via exports promotion and reduction of government deficit through reduction in spending.

\section{Deregulation and the Economy}

There is no gain saying that the existence of an unstable macroeconomic environment and the weakness in the economic programme or structure in the Nigerian economy gave rise to the introduction of deregulatory policy. Deregulatory policy in an economy aimed at eliminating policy that is inadequate as well as distortions of the old system governance. Deregulation deals with the removal of selected regulation in established business by the government are aimed at attaining a realistic exchange rate of the naira. Deregulatory rationalization is a process of estimating domestic production, specialization of procedures, dismantling of administrative controls of production and increase reliance or depends on market forces for the determination and pattern of resource allocation. The stated deregulatory measures above were designed to re-orient the economy towards free market in areas the intermediary and financial roles of banks become more relevant/ crucial to the economy. Deregulatory

policy have been practically focused on the following areas, namely, price and trade regulations which involves both domestic and foreign trade, interest rate deregulation which is the major focus of this paper and institutional deregulation.

Deregulation policy was given birth to by structural adjustment programme that was introduce in Nigeria in July 1986. Before the inception of deregulation, interest rate was highly regulated and there was frequent adjustment of interest rate with the aim of achieving monetary policy objective for the period under review. 


\section{Methods}

This paper uses the unit root, test co-integration methods and Chow Breakpoint test to analyze deregulation of interest rate and economic development. From the foregoing discussion, interest rate is one of the major components of deregulation. Thus, our model expresses national development as (GDP) as a function of various levels and components of deregulation that include interest rate (INR), inflation rate (INF), exchange rate (EXR), money supply (MS) and availability of credit (AOC) Thus, the growth model is specified as:

$\mathrm{GDP}=\beta \mathrm{o}+\beta 1 \mathrm{INR}+\beta 2 \mathrm{INF}+\beta 3 \mathrm{EXR}+\beta 4 \mathrm{MS}+\beta 5 \mathrm{AOC}+\mathrm{Ut}$

\section{Unit Root Test}

The Augmented Dickey Fuller (ADF) unit root test was used to assess whether the variables are stationary or not and their order of integration. The ADF is preferable to the Dickey Fuller (DF) test because it corrects for serial correlation in the variable. The result of the ADF unit root test is shown in table 4.1 below:

\section{Summary of ADF unit Root Test Result}

\begin{tabular}{|c|c|c|c|c|c|c|}
\hline Variables & Levels data & $1^{\text {st }}$ diff. & $\begin{array}{l}1 \% \\
\text { cri. value }\end{array}$ & $\begin{array}{l}5 \% \\
\text { cri. value }\end{array}$ & $\begin{array}{l}10 \% \\
\text { cri. Value }\end{array}$ & Status \\
\hline INR & -3.115040 & -6.534862 & -3.653730 & -2.957110 & -2.617434 & $\mathrm{I}(1)$ \\
\hline INF & -2.993178 & & -3.639407 & -2.951125 & -2.614300 & $\mathrm{I}(0)$ \\
\hline EXR & -0.251344 & -5.458124 & -3.646342 & -2.954021 & -2.615817 & $\mathrm{I}(1)$ \\
\hline MS & -2.047529 & -3.223327 & -3.724070 & -2.986225 & -2.632604 & $\mathrm{I}(1)$ \\
\hline AOC & 1.381714 & -8.008497 & -3.646342 & -2.954021 & -2.615817 & $\mathrm{I}(1)$ \\
\hline
\end{tabular}

Sources: Author calculation using E - Views. 
The Augmented Dickey Fuller (ADF) unit root test result suggests that Inflation Rate (INR) is stationary at levels, that is I(0). Interest Rate (INF), Exchange Rate (EXR), Money Supply (MS) and Availability of credit (AOC) became stationary at first difference, that is $\mathrm{I}(\mathrm{I})$. This can be seen by comparing the observed values (in absolute terms) of the ADF statistics at 1 percent, 5 percent and 10 percent levels of significance and Test critical values. Since all these stated variables were stationary at levels and first difference on the basis of that, the null hypotheses of non-stationarity is rejected and it is safe to conclude that the variables are integrated of order one, that is, I(1).

\section{Co-integration Test}

The Johansen co-integration test was used to test the long-run equilibrium relationship among the variables.

\section{Summary of Johansen test Result}

\section{Unrestricted Co-integration Rank Test (Trace)}

\begin{tabular}{|l|l|l|l|l|}
\hline Hypothesized No. of & Eigen Value & Trace Statistics & 0.05 critical & Prob.** \\
& & & & \\
& & & & \\
\hline None ${ }^{*}$ & 0.804462 & 163.0296 & 95.75366 & 0.0000 \\
\hline At most 1* & 0.745363 & 109.1735 & 69.81889 & 0.0000 \\
\hline At most 2* & & & & \\
\hline At most 3* & 0.680441 & 64.03232 & 47.85613 & 0.0008 \\
\hline At most 4 & 0.431471 & 26.38551 & 29.79707 & 0.1176 \\
\hline At most 5 & & & & \\
\hline & 0.204283 & 7.750333 & 3.841466 & 0.6472 \\
\hline
\end{tabular}

Trace test indicates 3 co-integrating eqn(s) at the 0.05 level

*denotes rejection of the hypothesis at the 0.05 level

**Mackinnon-Haug-Michelis (1999) p-values 
Journal of Economics and Sustainable Development ISSN 2222-1700 (Paper) ISSN 2222-2855 (Online)

Unrestricted Co-integration Rank Test (Maximum Eigenvalue)

\begin{tabular}{|l|l|l|l|l|}
\hline $\begin{array}{l}\text { Hypothesized No. of } \\
\text { CE(s) }\end{array}$ & Eigen Value & Trace Statistics & $\begin{array}{l}\mathbf{0 . 0 5} \text { critical } \\
\text { value }\end{array}$ & Prob.** \\
\hline None * & 0.804462 & 53.85606 & 40.07757 & 0.0008 \\
\hline At most 1* & 0.745363 & 45.14120 & 33.87687 & 0.0015 \\
\hline At most 2* & 0.680441 & 37.64681 & 27.58434 & 0.0018 \\
\hline At most 3* & 0.431471 & 18.63518 & 21.13162 & 0.1079 \\
\hline At most 4 & 0.204283 & 7.540883 & 14.26460 & 0.4273 \\
\hline At most 5 & 0.006327 & 0.209450 & 3.841466 & 0.6472 \\
\hline
\end{tabular}

Trace test indicates 3 co-integrating eqn(s) at the 0.05 level

*denotes rejection of the hypothesis at the 0.05 level

**Mackinnon-Haug-Michelis (1999) p-values

The result of the Johansen co-integration test indicates three (3) co-integrating equations. The trace statistics indicates three (3) co-integrating equation and the Maximum Eigenvalue statistics also indicate three (3) cointegrating equations. Following Harris (1995), in case of differences in the number of co-integrating equations the trace statistic supersedes.

\section{Chow Breakpoint Test}

\section{Summary of Chow Breakpoint Test: 1990}

Chow Breakpoint Test: 2002

Null hypothesis: No Breaks at specified break points

Varying regressor: All equations variables

Equation sample: 19802018
F-statistic
5.122988 Prob. $\mathrm{F}(7,22)$
0.0014
Log likelihood ratio 34.81199 Prob. Chi-square (7) 0.0000
Wald statistics $\quad 35.86091 \quad$ Prob. Chi-square (7) 0.0000

Source: Authors computation

The computed chow test statistics given in table 4.6 with F- statistics of $(5.122)$ and Prob. $F(7,22)=0.0014$ indicates that there is no break at the specified break points of deregulation. In this case we can conclude no evidence of break. This means that there is a significant change in the parameter of the model at that point. 


\section{Conclusion and Recommendations}

This paper summarily concludes that deregulation of interest rate has positive impact on exchange rate in Nigeria. So, interest rates can be deregulated. However, interest rate can be increased in response to deregulation without distorting availability of credit in Nigeria because availability of credit for investment purpose does not depend on interest rate alone. This is because, loan obtained from banks are not used for designated investment in Nigeria. Rather the funds are usually diverted to importation of goods and services and other areas, with this act the economy is subject to high rate of inflation due to exchange rate fluctuations. The empirical analyses also showed that money supply have very strong influence on deregulation in the Nigerian economy.

The study therefore recommended that efforts should be geared towards maintaining deregulation of interest rate, measure to enhance exchange rate and encourage savings should be maintained with a view to removing all impediments to free flow of businesses in the country. The monetary authorities should embark on routine efforts at bridging the widened gap between lending and savings rates to foster a moderate rise in nominal rates and stabilize inflationary pressure.

\section{References}

Akiri, E.S and I. Adofu (2007): Interest Rate Deregulation and Investment in Nigeria J. Econ, Management Study.

Central Bank of Nigeria: Economic and Financial Review (2012).Comparative Analysis, Bullim, CBN, Vol. 21, No 4

Colander, D. C (2001), “Economics” Boston McGraw Hill Irwin.

Ojo, M. O. (1993). Monetary Policy Instruments in Nigeria: Their Changing Nature and Implications. The Nigerian Banker, April-June, 6-8.

Opeyemi P, Egbewole O and Olusola O. (2014) The Impact of Deregulation of the Economy on Nigerian Commercial Banks; A Case Study of Some Selected Commercial Banks in Ilesa, Osun State. Australian Journal of Business and Management Research Vol.3 No.10

Soyibo, A. and Adekanye, F. (1992). "Financial System Regulation, Deregulation and Savings Mobilization in Nigeria" AERC Research paper, November, Nairobi

Tokunbo, S.O and Akinyele A.O (2006). "Commercial Bank Lending Rates and Real Sector of the Nigerian Economy" The Journal of Banking and Finance, vol. 8, No 2 